University of Rhode Island

DigitalCommons@URI

Open Access Master's Theses

2017

\title{
The Physiological Glucagon Receptor in Rat Heart
}

Kevin Agostinucci
University of Rhode Island, kagostinucci@my.uri.edu

Follow this and additional works at: https://digitalcommons.uri.edu/theses

Recommended Citation

Agostinucci, Kevin, "The Physiological Glucagon Receptor in Rat Heart" (2017). Open Access Master's Theses. Paper 1122.

https://digitalcommons.uri.edu/theses/1122

This Thesis is brought to you for free and open access by DigitalCommons@URI. It has been accepted for inclusion in Open Access Master's Theses by an authorized administrator of DigitalCommons@URI. For more information, please contact digitalcommons-group@uri.edu. 


\section{THE PHYSIOLOGICAL GLUCAGON RECEPTOR IN}

RAT HEART

BY

KEVIN AGOSTINUCCI

\section{A THESIS SUBMITTED IN PARTIAL FULFILLMENT OF THE \\ REQUIREMENTS FOR THE DEGREE OF \\ MASTER OF SCIENCE \\ IN}

BIOMEDICAL AND PHARMACEUTICAL SCIENCE

UNIVERSITY OF RHODE ISLAND

2017 


\section{MASTER OF SCIENCE IN BIOMEDICAL AND PHARMACEUTICAL SCIENCE $\mathrm{OF}$ KEVIN AGOSTINUCCI}

APPROVED:

Thesis Committee:

Major Professor $\quad$ Robert L. Rodgers
Abraham Kovoor
Michael Dunn
Thomas Manfredi
Nasser H. Zawia
DEAN OF THE GRADAUATE SCHOOL




\begin{abstract}
The actions of glucagon have been extensively studied for many years. In heart, it is well established that glucagon is capable of causing inotropy. This action is mediated by glucagon binding to a G-protein coupled receptor (GPCR) which activates adenylate cyclase, increasing the intracellular concentrations of cAMP. The studies that were able to show this effect used concentrations of glucagon that were considered to be much higher than what is normally found in blood. A recent report, by Harney and Rodgers (2008), described the actions and signaling mechanisms of physiological concentrations of glucagon $\left(<10^{-10} \mathrm{M}\right)$ on perfused rat hearts. These investigators were also able to show that a peak physiological concentration of glucagon $\left(10^{-10} \mathrm{M}\right)$ increased glucose uptake in the same preparation. It was also found that this action was mediated by the activation of the PI3K/AKT signaling pathway. The missing piece of this mechanism to fully show glucagon's action is the receptor responsible for glucagon binding and initiation of the reported downstream signaling effects. We hypothesize that one of two situations would occur: 1) the glucagon receptor that mediates glucose uptake is a GPCR or 2) there is a novel glucagon receptor responsible for the effects observed at low concentrations. Hearts were removed from male Sprague Dawley rats ( $n=1-6 /$ grp) and isolated heart perfusion methods, either Langendorff or working mode, were used to deliver a physiological solution to the heart. Specific concentrations of hormone, one which represents peak physiological glucagon levels and another that represents a concentration of glucagon too high to be normally found in blood, were added to the physiological solution. An anti-glucagon receptor antibody was obtained which was
\end{abstract}


used to block the known glucagon receptor. Hearts were treated with no hormone or with the following treatments: 1) $10^{-10} \mathrm{M}$ glucagon; 2) $4 \times 10^{-10} \mathrm{M}$ insulin; 3) $10^{-8} \mathrm{M}$ glucagon; 4) $10^{-8} \mathrm{M}$ glucagon plus antibody and 5) $10^{-10} \mathrm{M}$ glucagon plus antibody. Immediately after perfusion, hearts were processed and probed for AKT activation. It was found that glucagon concentrations at $10^{-10} \mathrm{M}$ did not induce an inotropic response during Langendorff perfusion, while glucagon concentrations at $10^{-8} \mathrm{M}$ was able to. For working mode, an inotropic response was not observed when hearts were perfused with $10^{-10} \mathrm{M}$ glucagon and $10^{-8} \mathrm{M}$ glucagon. There was no observable activation in AKT after physiological glucagon treated hearts in either Langendorff or working mode perfusion methods. In conclusion, the receptor that mediates glucagon's actions at physiological concentrations was not able to be characterized from these experiments. Experimental strategy should be revised to optimize ex vivo heart perfusion method and include additional in vitro experiments to conclude the identity of the glucagon receptor. 


\section{ACKNOWLEDGMENTS}

I would like thank Dr. Rodgers for the opportunity to work in his laboratory and providing me with a great learning experience. Dr. Rodgers spent numerous hours teaching me specific content pertaining to my project and training me to become a successful scientist. Because of his mentorship, I developed a passion for science.

Dr. Dunn who spent numerous hours teaching and mentoring me was also essential to the completion of my project. Dr. Dunn played an active role in training me to perform my techniques, troubleshooting various aspects of my project, and provided guidance in writing my thesis.

I would also like to thank Drs. Kovoor, and Manfredi both who were essential for the completion of my project. These mentors provided important feedback in regards to troubleshooting my project, analyzing the data, and writing my thesis. Without their assistance, I would not have been able to complete my project.

Finally, I would like to thank my mother and father for their loving support. They provided me with constant encouragement and support which help me get through tough times during my graduate school experience. 


\section{TABLE OF CONTENTS}

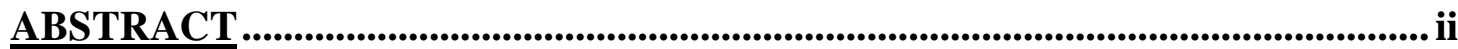

ACKNOWLEDGMENTS ...................................................................................................... iv

LIST OF FIGURES ........................................................................................ vi

CHAPTER 1 ................................................................................................................. 1

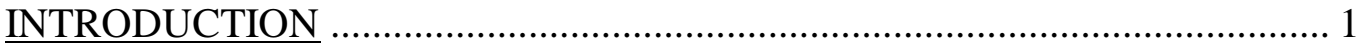

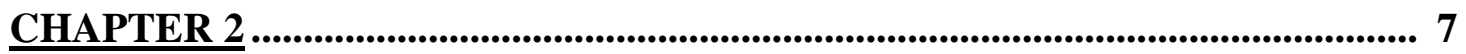

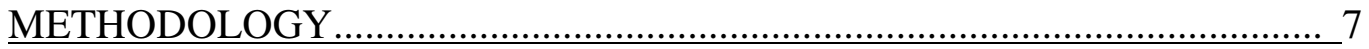

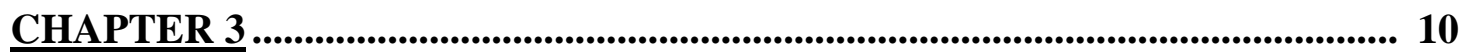

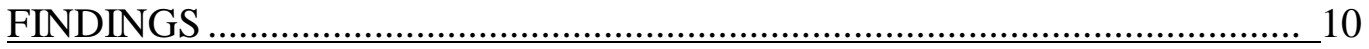

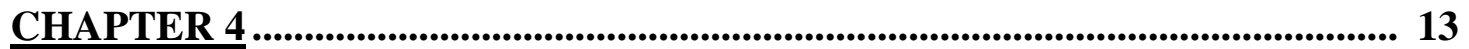

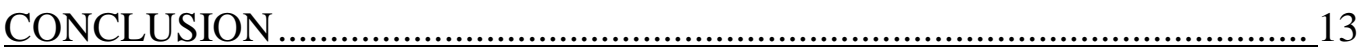

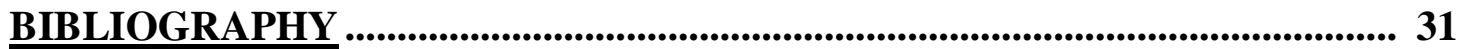




\section{LIST OF FIGURES}

FIGURE

PAGE

Figure 1. Representative Left Ventricular Pressure Tracing During Langendorff

Perfusion.

Figure 2. Average Left Ventricular Pressure for each group during Langendorff

Perfusion.

Figure 3. Representative Left Ventricular Pressure Tracing During Working Mode

Perfusion

24

Figure 4. Average Left Ventricular Pressure for each group during Working Mode

Perfusion

Figure 5. Left Ventricular Pressure Tracing 30 Seconds after supra-physiological

glucagon administration working mode perfusion. 26

Figure 6. Left Ventricular Pressure Tracing one minute after supra-physiological

glucagon administration during working mode perfusion.

Figure 7. Left Ventricular Pressure Tracing five minutes after supra-physiological

glucagon administration during working mode perfusion.

Figure 8. Average AKT activation after Langendorff perfused hearts in each treatment group

Figure 9. Average AKT activation after working mode perfused hearts in each treatment group 


\section{CHAPTER 1}

\section{INTRODUCTION}

Glucagon is a 29-amino acid peptide that is manufactured in alpha cells of the pancreas (Jiang and Zhang, 2003). This peptide is a vital player in regulating glycemia by acting in opposition to the effects of insulin. When blood glucose and insulin are low, the tonic inhibitory effect of insulin is removed and glucagon can be released from the pancreas (Taborsky, 2010). Glucagon is transported in the blood to its primary effector organ, the liver. As the ratio of glucagon to insulin increases, glucagon's action will be more prominent than insulin's action (Unger, 1971). The major effect of glucagon is to promote glucose output by increasing glycogenolysis and gluconeogenesis. In addition, glucagon can also act on the heart and adipose tissue by increasing contractility and lipolysis, respectively (Rodgers, 2012).

A G-protein coupled receptor (GPCR) is the main molecular target for glucagon (Jiang and Zhang, 2003; Rodgers, 2012). GPCR's are a type of receptor that contains a seven-transmembrane domain plus a heterotrimeric G-protein complex (Salazar et al., 2007). When glucagon binds to a GPCR, a signaling cascade is initiated. First, $\mathrm{G}_{\alpha \mathrm{s}}$ subunits are activated and dissociate from the G-protein complex, which causes an increase in cyclic adenosine mono-phosphate (cAMP) by increasing the activity of a membrane-bound enzyme called adenylate cyclase (AC). cAMP then activates protein kinase A (PKA) by binding to the regulatory subunit causing it to dissociate from the catalytic subunit. PKA can phosphorylate certain proteins which causes an action at the specific organ (Rababa'h et al., 2014; Towle, 2001). 
The action of glucagon has been studied for many decades. The known actions of glucagon on liver, adipose tissue, and heart occur when glucagon binds to a GPCR to activate the AC/cAMP dependent pathway. The problem with these described actions is that they only occur at supra-physiological (glucagon concentration $>0.1 \mathrm{nM}$ ) levels, which do not reflect the physiologic concentrations (glucagon concentration $<0.1 \mathrm{nM}$ ) found in vivo (Rodgers, 2012). This was illustrated by constructing average dose-response curves from numerous studies. For adipose and heart, the $\mathrm{EC}_{50}$ value of glucagon to produce the organ's specific action, and the generation of cAMP, overlap each other and are well outside the concentration normally found in blood (Henry et al., 1975; Jean-Baptiste et al., 1982). This supports the claim that glucagon does not produce these actions in vivo. For liver, the $\mathrm{EC}_{50}$ value of glucagon to increase cAMP is well outside glucagon's physiological concentration. However, it can be shown that glucagon can cause the liver to generate similar or identical responses at much lower concentrations without activating adenylate cyclase (Clark and Jarrett, 1978; Ikezawa et al., 1998a). Since the curves for glucose output and concentration of tissue cAMP do not overlap, one can make the assertion that glucagon's action on the liver can occur through an alternative signaling mechanism in vivo. Collectively, these results raise the question about the "physiological relevance" of glucagon to produce these actions via the AC/cAMP dependent pathway. In order for a hormone's action to be considered "physiologically relevant", the action of the organ must occur at concentrations normally found in blood (Rodgers, 2012). It is evident from these graphs that glucagon can only generate cAMP-dependent cellular effects when concentrations are well above physiological 
levels. Thus, additional research should be conducted to elucidate the physiological action of glucagon in liver, adipose tissue, and heart.

Studies have shown in liver that physiological and supra-physiological concentrations of glucagon activate two different signaling pathways but cause the same action (Livingston et al., 1985; Wakelam et al., 1986). The first piece of evidence comes from dose-response curves. Glucagon at physiological concentrations was able to increase glucose output without any increase in cAMP in perfused rat livers (Pilkis et al., 1974). Binding studies were also performed and it was found that supra-physiological glucagon concentrations were needed to activate the lower affinity glucagon receptor linked to AC. In the study performed by Bonnevie-Nielsen and Tager (1983), they determined $K_{d}$ values for two different population of glucagon receptors. The $\mathrm{K}_{\mathrm{d}}$ values of the low affinity glucagon receptor was $0.54 \mathrm{nM}$ in hepatocytes and $92 \mathrm{nM}$ in liver vesicles. Both these $\mathrm{K}_{\mathrm{d}}$ values are above physiological concentrations. The high affinity receptor had $\mathrm{K}_{\mathrm{d}}$ values of $0.19 \mathrm{nM}$ and $2.6 \mathrm{nM}$ in hepatocytes and liver vesicles respectively (Bonnevie-Nielsen and Tager, 1983). At physiological concentrations, glucagon binds with higher affinity to a receptor not linked to AC. It was found that the high affinity receptor participated in a calciumdependent signaling pathway that also increased glucose output (Ikezawa et al., 1998b). A molecular cloning study was performed to identify the receptor that binds to glucagon. The experimenter expressed the glucagon receptor in kidney cell lines and measured $\mathrm{K}_{\mathrm{d}}$ values. According the Schatchard plot they developed, they found two $\mathrm{K}_{\mathrm{d}}$ values for the glucagon receptors that they expressed. However, the authors were not able to conclude that the receptors were anything other than the GPCR (Jelinek et 
al., 1993). Thus, one prominent hypothesis is that two glucagon receptors are GPCRs, with two different affinities to glucagon, that can either undergo the AC/cAMP or PLC/IP3 signaling pathways.

Adipose tissue also has been shown to respond to glucagon at supraphysiological concentrations via the cAMP/AC dependent pathway. However, the available evidence does not support the existence of a physiological receptor for glucagon in adipose tissue. The average dose response curves produces a monophasic curve with an $\mathrm{EC}_{50}$ that lies well outside physiological glucagon concentrations (JeanBaptiste et al., 1982). Furthermore, the average $\mathrm{EC}_{50}$ and $\mathrm{K}_{\mathrm{d}}$ was calculated from many studies and it was shown that these values were similar (Rodgers, 2012). The similar values show that an additional receptor is not present in adipose tissue. Thus, it is believed that glucagon does not have any action in vivo on adipose tissue.

It has been demonstrated multiple times, and in many experimental models, that glucagon causes the heart to generate more force at a faster rate. Because of this, the claim has been made that glucagon's acts to activate inotropic and chronotropic responses on the heart, both which are accompanied by increase in cAMP. Dr. Robert Rodgers and his colleagues believe that these effects cannot be the in vivo action of glucagon because concentrations above physiological levels are needed for this to occur. Dr. Rodgers constructed a concentration-effect curve that represents the findings of multiple sources to show the action of glucagon on the heart (Rodgers, 2012). From his curve, he shows that $\mathrm{EC}_{50}$ values for inotropy and $\mathrm{cAMP}$ concentration both lie well outside of the glucagon concentration found in blood. Thus, his laboratory was interested in seeking out glucagon's in vivo cardiac action. 
They found that at physiological glucagon concentrations, glycolysis increased and palmitate oxidation decreased in isolated perfused working hearts (Harney and Rodgers, 2008). These actions are the same as insulin's actions and our experiments showed that there was no statistical difference between the actions produced by either glucagon or insulin (Harney and Rodgers, 2008; Rodgers et al., 2001a). Furthermore, a physiological glucagon concentration activated a PI3K/AKT pathway but had no effect on the cAMP/AC pathway. This is another component that is shared between glucagon and insulin (Harney and Rodgers, 2008; Saltiel and Kahn, 2001). they were able to show that glucagon mimics the action of insulin, rather than opposing it, in heart at a physiological concentration.

The glucagon receptor that mediates the insulin-like response has yet to be identified. The purpose of this investigation was to begin to explore the identity of this receptor by performing heart perfusions followed by western blot analysis. The isolated heart perfusion method was used because the physiological parameters of the heart could be measured independent of any neuro-hormonal influence, the heart is in an environment where all substrates and substrate levels are known, and without an confounding effects from other metabolically active organs (Skrzypiec-Spring et al., 2007). Hearts were treated with specific concentrations of hormone (physiological or supra-physiological) and contractility was measured to see if the hormone could activate the known GPCR. To block the known GPCR, an anti-glucagon GPCR antibody was obtained and put into a solution that was perfused through the heart. Hearts were then subjected to western blot analysis after perfusion experiments to show AKT activation. We hypothesized: 1) A GPCR linked to PI3K/AKT mediates 
the insulin-like action of glucagon or 2) A receptor of a different class linked to PI3K/akt mediates the insulin-like action of glucagon. 


\section{CHAPTER 2}

\section{METHODOLOGY}

\section{Methods:}

Animal usage:

All procedures for the use of animals were approved by the University of Rhode Island Animal Care and Use Committee. Male rats were purchased from vendors (Taconic or Charles River). Animals were co-housed in standard cages with a 12-hour light-dark cycle. They provided water and standard chow ad libitum., and body weights were collected routinely.

Preparation of solutions:

Hearts were perfused with Krebs-Henseleit $(\mathrm{K}-\mathrm{H})$ solution with the following composition (mM): $\mathrm{NaCl}, 120 ; \mathrm{CaCl}_{2} \bullet 2 \mathrm{H}_{2} \mathrm{O}, 1.8 ; \mathrm{NaH}_{2} \mathrm{PO}_{4} \bullet \mathrm{H}_{2} \mathrm{O} 1.2 ; \mathrm{MgSO}_{4} \bullet 7 \mathrm{H}_{2} \mathrm{O}$, 0.65 and $\mathrm{KCl}, 5.6$, glucose, 10; and $\mathrm{NaHCO}_{3}, 25$. Working and Langendorff heart preparations were perfused with $\mathrm{K}-\mathrm{H}$ solution containing $3 \%$ and $0.1 \% \mathrm{BSA}$, respectively. In both preparations, the solution was gassed with $95-5 \% \mathrm{O}_{2}-\mathrm{CO}_{2}$

Hearts were treated with one of the following: 1) no hormone; 2) insulin $\left(4 \times 10^{-10} \mathrm{M}\right)$ (Sigma-Aldrich); 3) and glucagon $\left(10^{-10}\right.$ or $\left.10^{-8} \mathrm{M}\right)$ (Sigma-Aldrich). The lower and higher glucagon concentrations represented physiological and supraphysiological concentrations (Rodgers, 2012).

\section{Isolated Heart Perfusion:}


The isolated heart perfusion technique was used to measure the hearts contractility when administering different treatments. The two types of perfusion techniques used were the Langendorff (Skrzypiec-Spring et al., 2007) and the working mode preparation (Harney and Rodgers, 2008; Rodgers et al., 2001b), both which have been described previously. Both preparation allows for the delivery of K-H solution to the coronary arteries of the heart so it can contract without being inside the animal. The pressure produced during perfusion was measured using a Millar catheter (SPR-524) inside a K-H solution filled column which was connected to the left ventricle. Pressure data was collected using Data Translation software (Colorado Springs, $\mathrm{CO}$ ) and the data was analyzed using ADinstruments Lab Chart software. At the end of the perfusion, hearts were snapped frozen in liquid nitrogen and store in $80^{\circ} \mathrm{C}$ freezer.

\section{Western Blot and AKT probing:}

The procedure used to isolate proteins from the heart tissue was established by Harney and Rodgers (2008). Briefly, left ventricles of the heart were isolated then added to a lysis buffer containing the following solutes $(\mathrm{mM}) \mathrm{NaCl}-150$; Tris- $\mathrm{HCl}-$ 50; $\mathrm{NaVO}_{4}-1 ; \mathrm{EDTA}-5$; PMSF -1 ; and protease tablet. Tissues were homogenized and centrifuged at the following speeds (times g): 1,000; 100,000; and 15,000. The final solution contained only soluble proteins. Proteins in solution were quantified using BCA assay kit.

Protein in solution were separated via SDS-PAGE. Equal amount of protein was added to each lane of a $10 \%$ gel and were electrophoresed at $100 \mathrm{~V}$. At the 
completion of the electrophoresis, electroblotting was performed to transfer proteins from the polyacrylamide gel to a PVDF membrane. Electroblotting proceeded at $30 \mathrm{~V}$ for 30 minutes.

Anti-AKT and anti-phospho-AKT (S473) were purchased from Cell Signaling Technologies and were used according to manufacturer's protocol. Proteins were visualized using Biorad ChemiDoc imaging. ImageJ software was used to quantify the signal that was developed by the imaging software. 


\section{CHAPTER 3}

\section{FINDINGS}

It is well established that high concentrations of glucagon are capable of inducing an inotropic response on the heart (Gonzalez-Muñoz et al., 2008; MacLeod et al., 1981; Rodgers et al., 1981). This response is mediated by the known glucagon GPCR linked to AC/cAMP. Physiological glucagon concentrations and insulin should not be able to induce this response (Fu et al., 2014; Harney and Rodgers, 2008). Therefore, we tested this theory by administering either $0.4 \mathrm{nM}$ of insulin, $0.1 \mathrm{nM}$ (physiological concentration) or 10nM (supra-physiological) of glucagon to isolated perfused hearts and measure the pressure produced by the left ventricle.

Figure 1 is a representative pressure tracing of one heart perfused via the Langendorff preparation. From this figure, the left ventricular developed pressure (LVDP) can be determined by taking the difference between the peak systolic and diastolic pressures. The developed pressures were calculated for each heart and the average pressures were determined for each hormone group. The average LVDP values are represented in figure 2 . Hearts that were perfused with no hormone had an average pulse pressure of $65.6+/-7.06 \mathrm{mmHg}$ (mean +/- SEM). When 0.4nM insulin or $0.1 \mathrm{nM}$ of glucagon the pressure produced were $68.02+/-13.11 \mathrm{mmHg}$ and 80.67 +/- $19.78 \mathrm{mmHg}$, respectively. This is in line with what we were expecting because peak physiological concentration of either insulin or glucagon is not capable of inducing inotropy (Fu et al., 2014; Harney and Rodgers, 2008). Hearts produced the 
largest inotropic response after administration of glucagon at supra-physiological concentrations, as expected. The pressure that was developed for supra-physiological glucagon administration was $133.11+/-6.67 \mathrm{mmHg}$.

Hearts that were perfused via working mode produced higher pressures, with all treatments, compare to hearts perfused in the Langendorff mode. Figure 3 is a representative pressure tracing of a heart perfused in the working mode. The same calculations were performed, as for figure 1 , and average pressures were determined for each group and are represented in figure 4 . Hearts produced pressures of 110.80 +/- $10.7 \mathrm{mmHg}, 100.85 \mathrm{mmHg}, 90.95+/-24.6 \mathrm{mmHg}$ and $92.96+/-4.18 \mathrm{mmHg}$ when administered with no hormone, $0.4 \mathrm{nM}$ insulin, $0.1 \mathrm{nM}$ glucagon, and $10 \mathrm{nM}$ glucagon respectively. Unlike what was observed in hearts administered with 10nM glucagon via Langendorff perfusion, the average pressure of $10 \mathrm{nM}$ glucagon was less than that of control in the working mode. Figures 5 and 6 are representative tracings of a heart perfused with a supra-physiological glucagon concentration. It can be seen that an increase in contractility did occur. However, the response eventually decreased as the heart progressed through the perfusion which explains why the average pressure was less than control (figure 7).

It has been determined in this laboratory that, not only does a physiological concentration of glucagon mimic the same physiological action of insulin in the heart, but it also shares the same signaling pathway (Harney and Rodgers, 2008). It is well established that insulin binds to the insulin receptor which activates PI3K followed by AKT to increase glycolysis (Lee and Pilch, 1994). Evidence from this laboratory shows that glucagon at physiological concentrations also activates the PI3K/AKT 
signaling pathway. Thus, we used this signaling pathway to assess the claim that changes in cardiac glycolysis could occur independently of changes in cardiac contractility with physiological concentrations of glucagon. The PI3K/AKT signaling pathway was quantified by measuring total amounts of AKT and the amount of phosphorylated AKT. A phosphorylated AKT:total AKT ratio was calculated to assess the activation of this signaling pathway when a hormone is given to the heart. For hearts perfused in Langendorff mode, an average P-AKT/T-AKT of $0.468+/-0.076$ $($ mean $+/$ - SEM) was observed for untreated hearts. The highest P-AKT/T-AKT ratio that was observed was when insulin was administered to the hearts $(0.561+/-0.128)$. Supra-physiological glucagon concentrations produced the second highest ratio of $0.603+/-0.236$. Administration of physiological glucagon produced the smallest a PAKT/T-AKT ratio of $0.221+/-0.032$.

AKT quantification was also assed in hearts perfused in the working mode. A value of $0.468+/-0.076$ was observed for untreated hearts. Administration of insulin to hearts gave the highest $\mathrm{P}-\mathrm{AKT} / \mathrm{T}-\mathrm{AKT}$ ratio compared to the other groups (1.168). Supra-physiological glucagon produced the second highest P-AKT/T-AKT ratio of $0.719+/$ - 0.068. Finally, administering physiological glucagon produced an P-AKT/TAKT ratio of 0.472. +/- 0.099. 


\section{CHAPTER 4}

\section{CONCLUSION}

The quintessential action of glucagon is to increase contractility of the heart. However, studies proved that this only happens at supra-physiological concentrations. In the laboratory of Dr. Robert Rodgers, they were able to find a different action of glucagon at physiological concentrations. Glucagon increased glucose uptake, glucose oxidation, and decreased palmitate oxidation to a degree similar to insulin (Harney and Rodgers, 2008; Rodgers et al., 2001a). Furthermore, physiological concentrations of glucagon activated the PI3K/AKT pathway without any activation of AC/cAMP (Harney and Rodgers, 2008). Therefore, we believe that increasing cardiac contractility is not the main in vivo action of glucagon.

The first objective of this study was to determine whether a supraphysiological concentration of glucagon increases inotropy compared to physiological concentrations in Langendorff perfused hearts. A supra-physiological concentration of glucagon was able to produce an average LV pulse pressure that was greater compared to controls in Langendorff perfused hearts. Hearts perfused with a physiological concentration of glucagon or insulin produced LV pressures that were modestly elevated compared to control hearts. This result was consistent with previous reports (Harney and Rodgers, 2008; Tuncok et al., 1997). Hearts perfused with any of the hormone treated groups, in working mode, did not produce an average LV pulse pressure that was larger compared to controls. An inotropic response was expected to 
occur in hearts treated with supra-physiological glucagon concentrations because it has been previously reported that high glucagon concentrations increase developed tension or pressure in rat hearts or cardiac muscle preparations (MacLeod et al., 1981; Rodgers et al., 1981). Although the average response was not different, it appears that a transient inotropic response was produced. This observation can be explained by glucagon's tachyphylaxis response. Tachyphylaxis response, in heart, occurs when there is a rapid increase in left ventricular pressure which is then decreases back to baseline shortly after (MacLeod et al., 1981). This response occurs in G-protein signaling due to either receptor desensitization or by activity of phosphodiesterases that degrades cAMP. Fita-Juan and colleagues (2004), studied the tachyphylaxis response in isolated right ventricle strips in rats. When glucagon was added to these hearts, a transient (<2min) inotropic response was induced (Juan-Fita et al., 2004). In this study, it was observed that the inotropic response was at its highest point one minute after glucagon administration, then rapidly decreased.

The second objective was to determine whether a physiological concentration of glucagon was able to activate the PI3K/AKT signaling pathway. We evaluated activation of PI3K/AKT pathway by quantifying phosphorylated AKT and total AKT via western blots. For Langendorff and working mode perfused hearts, there appears to be no increase in AKT activation between physiological glucagon treated hearts compared to untreated hearts. This was contrary to Harney and Rodgers's report which showed PI3K/AKT activation when hearts were perfused with low concentrations of glucagon. A physiological concentration of insulin produced more activation in AKT compared to untreated hearts in either Langendorff or working mode perfusion 
methods. Due to the small number of subjects in the insulin treated group, the values obtained cannot definitively show that insulin was capable of activating AKT at a higher magnitude compared to untreated hearts.

Differences in methodology could explain the unexpected results that were observed in this experiment. One factor that may explain the discordant results is the difference in the age range of rats enrolled in each study. In the current experiment, the age was not recorded but, the age can be approximated using body weight (2017). Harney and Rodgers (2010), used rats that weighed between 200-400 grams which approximates to two to three months. In this experiment, it was noted that many of the animals that were used weighed over 400 grams with is approximately three months or older.

Another point that arises, due to the unexpected results, is whether or not the glucagon used was sufficient to activate AKT. The glucagon that was used may have lost intrinsic activity to activate the glucagon receptor, or, the dilution procedure was not accurate and low than expected concentrations of glucagon was administered to the perfused heart. A crucial experiment that can give evidence to the integrity of the glucagon solution was to perfuse hearts with $5-{ }^{3} \mathrm{H}$-glucose and measure the change in rate of glycolysis. If glucagon administration was able to activate glycolysis, but not $\mathrm{PI} 3 \mathrm{~K} / \mathrm{AKT}$, then it can be argued that glucagon's physiological actions are not mediated by PI3K/AKT.

Aging can affect the biochemical and physiological parameters of this experiment. First, the strength of the PI3K/AKT signaling pathway could have decreased due to using older rats. Griecsova and colleagues (2015), showed that three- 
month-old rats had a lower AKT activation than 1.5 months old rats (Griecsová et al., 2015). In this study, several rats weighed over 400 grams which approximate to a 3 month-old rat. This may explain why AKT activation was not as robust as expected after insulin treatment. This could also be a factor that cause physiological glucagon treated hearts to have a lower than expected AKT activation.

A decline in cardiac performance can also be attributed to changes in the GPCR receptor signaling. These changes include reductions in the: 1) number of receptors, 2) sensitivity of the receptor and 3) downstream actions after receptor activation. In a study performed by Xiao et al (1998), they found that age related declines in LV contractility were due to decreases in the number of $\beta$-adrenergic receptors. It was also determined from this study that older rats have less AC activity compared to young rats when a ligand binds to the receptors (Xiao et al., 1998). Furthermore, heart contractility decreased due to changes in calcium handling after $\beta$ adrenergic stimulation. It was found that calcium levels were decreased in older animals compared to younger ones which will reduce the strength of contraction (Ferrell and Howlittt 2007). It was shown that decreases in calcium levels during diastole can decrease the contraction force at the next heartbeat. Since the glucagon receptor is also a GPCR associated with $\mathrm{AC}$, it can be expected that similar changes can occur due to aging which may have affected the hearts ability to contract.

Fibrosis of heart tissue is another possible factor that may explain the lower than expected pressure produced by the hearts. Age-related fibrosis increases collagen deposits into the heart's extracellular matrix and causes a decrease in performance. In ideal conditions, the extra cellular matrix plays an important role in maintaining the 
organs structure that allows it to work normally (Heeneman et al., 2003). For certain conditions (i.e. aging) there may be an overproduction of extracellular matrix proteins which decreases the hearts ability to perform. In an experiment conducted by Sangaralingham et al., they showed that collagen production in the left ventricle was higher in 20-month-old Fisher rats than in two- months old rats (Sangaralingham et al., 2016). This increase in fibrosis was accompanied by decreases in ejection fracture and decreases in diastolic wall tension.

Evidence is also present that shows young Sprague-Dawely rats are prone to develop spontaneous cardiac lesions. In a study conducted by Chanut et al. (2013), they looked at the presence of lesions in different regions of the heart and they found the highest occurrence of lesions to be within the myocardium of the left ventricle. It was also reported that the stress from handling the rats had no effect on changing the occurrence of the lesions (Chanut et al., 2013). This can have an effect on the pressure generated by the heart. The presence of cardiac lesion can cause an inflammation response that may release factors which can decrease LV function. For example, it has been shown that TNF (a pro-inflammatory agent) infusion resulted in reduced inotropic response which was reversed when TNF was removed (Mann, 2002). Depending on the size and number of lesions in the heart, this may have contributed to the lower than expected pressure development of the left ventricle.

If this experiment was to be redone, a different approach for identifying the PI3K/AKT signaling pathway would be necessary. One method that can be utilized are cell culture techniques followed by western blot analysis to probe the same proteins. Isolated cardiomyocytes can be obtained from whole heart by perfusing it with 
digestive enzymes via Langendorff perfusion (Louch et al., 2011). The isolated cell can then be plated onto a culture dish and be given culture media. In the culture media, different concentrations of hormone can be given to the cardiomyocytes and protein quantification can be determined via western blotting.

Western blot analysis have been performed on hepatocytes and probed for AKT (Aw et al., 2014; Zhao et al., 2000). In these experiments, glucagon was not able to activate the PI3K/AKT signaling pathway. This observation can be explained by the fact that the receptors present in the liver are not linked to PI3K/AKT. However, this author was not able to find any reports that performed cell culture experiments on isolated ventricular cardiomyocytes treated with glucagon. Performing this method may provide evidence on the physiological signaling cascade of glucagon.

Instead of using ex vivo hemodynamics to measure the contractility of the heart, in vitro video edge detection of isolated ventricular cardiomyocytes could be used to measure a single myocyte's ability to shorten (Bazan et al., 2010). There is evidence that the cardiomyocyte has glucagon receptors on it so the changes in contractility can be measure when cell are perfused with glucagon containing solution (Ali et al., 2015; Méry et al., 1990; Tang and Insel, 2004). It has the advantage over ex vivo measurements of contractility because the experimenter is directly measuring the ability of a single myocyte to shorten when given a certain stimulus. The contractility of many myocytes can be measured which may provide evidence for how the cells will function in the intact organ. A limitation of this method is that the results may not represent what is occurring at the organ level. Whole heart perfusion methods incorporate preload and after load, both which influence the tension that can be 
developed in the LV (Schechter et al., 2014). Furthermore, measuring contractility in isolated cardiomyocytes does not represent how the heart may act in vivo because the cells are not connected to each other. Gap junctions are channels which connect the intracellular content between two cardiomyocytes. These channels allow ionic current to pass directly from one cardiomyocyte to another which allow the whole heart to contract in a synchronized manner (Rook et al., 1992). Interruption of this current through each cardiomyocyte can prevent the ventricles from depolarizing and thus fail to contract. Contractility can be measured using cell based experiments. Threedimensional cell culture techniques allow for an experimenter to grow cells that does not limit the cells to grow on a flat surface. Cells are able to form connections with each other that may closer replicate what happens in vivo. In a report by Shimizu et al., they were able to measure cell shortening in cultured cardiac tissue grafts by using a digital video camera (Shimizu et al., 2002).

\section{Limitations:}

The surgical procedure used in this study was similar to the procedure performed by Harney and Rodgers (2010). The experimenter tried to replicate the same conditions that Harney used when performing the heart isolation, but the experimenter was not there to observe Harney perform the procedure. It was thought

that differences in experimenter's ability to isolate the heart could have contributed to the different results. Differences such as speed of heart isolation and location of cannula placed on the aorta could have affected the outcome of the procedure. Using anesthesia could have facilitated in the heart isolation process by reducing the stress 
put on the animal. Minimizing the stress on the heart may reduce the damage put on the heart while the experimenter performs the heart isolation procedure.

Another limitation of this experiment is that absolute pressure values were recorded, rather than changes in pressure relative to baseline. Changes in LV pulse pressure from baseline is a better marker for contractility. The reason is that there are many factors that can influence the amount of force the heart can produce; such as changes in pre-load and afterload, health of the heart, or quality of solutions used to treat heart. Contractility is the heart's ability to increase the amount of force independent of pre-load and/or after load. Recording the change in LV pulse press will rule out some of the effects of extrinsic factors that may change the pressure the heart produces. With absolute pressures, we can see that different pressures are generated but we cannot fully conclude that the pressures generate was due to the heart's intrinsic ability to develop more force.

\section{Conclusion}

In summary, it cannot be determined if a high concentration of glucagon was able to induce an inotropic response. LV pressure was the highest in supraphysiological treated hearts perfused in Langendorff mode. However, LV pressure was similar between untreated and supra-physiological glucagon administered hearts. The data also shows that there were no changes in AKT activation among the four groups. A limitation in this study that can explain why difference in measurements were not detected were due to the number of rats in each group. Since some of the treatment groups had less than four animals, statistics were not able to be performed to 
determine if there was a difference in values for LV pressure development and AKT activation. 


\section{Figures}

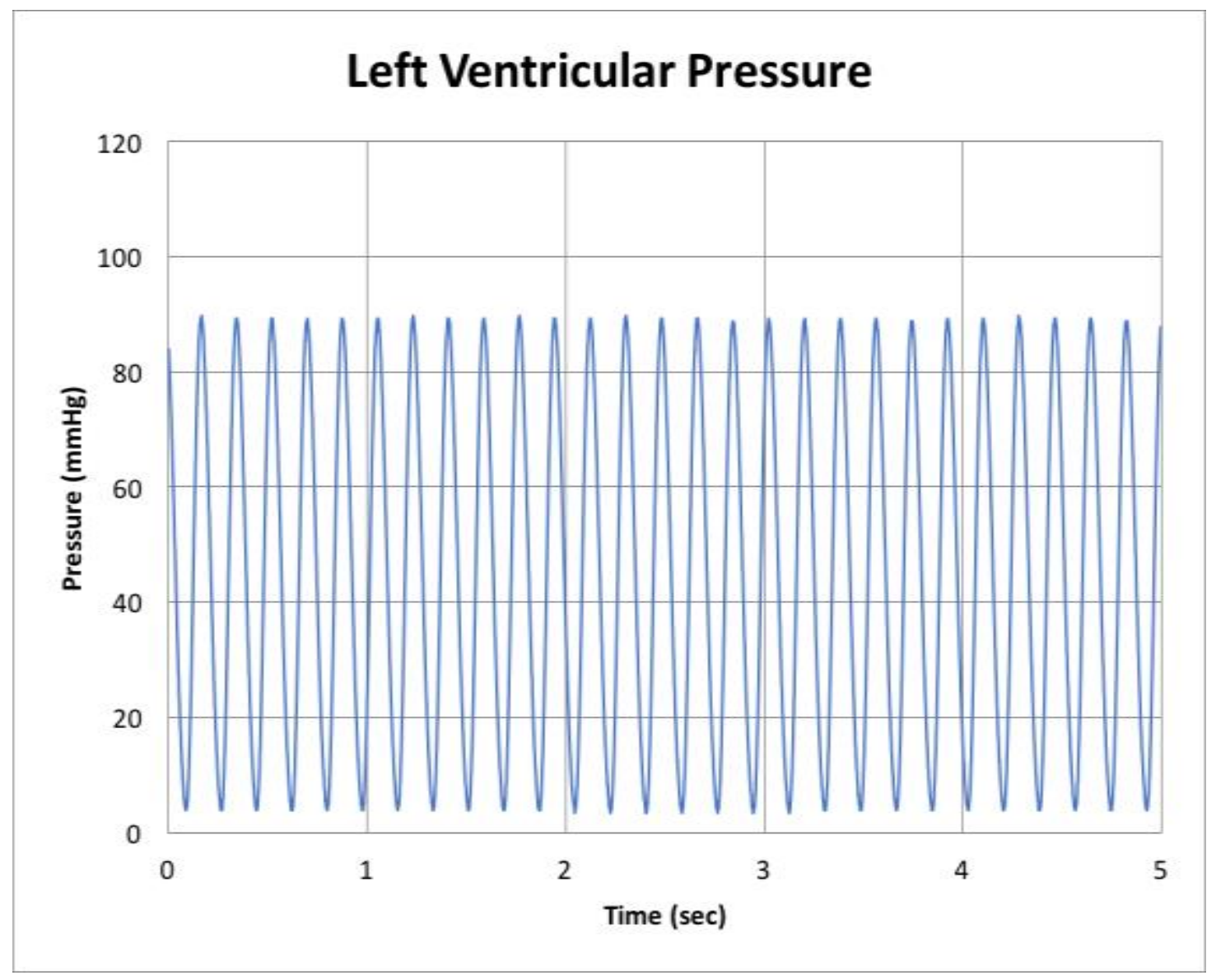

Figure 1: Representative pressure measurement for a heart perfused in the Langendorff preparation. This graph was shows the pressure produced by the left ventricle after 1 minute of perfusion. The difference between the maximum and minimum pressure were averaged to determine pulse pressure. This heart was treated with no hormone. 


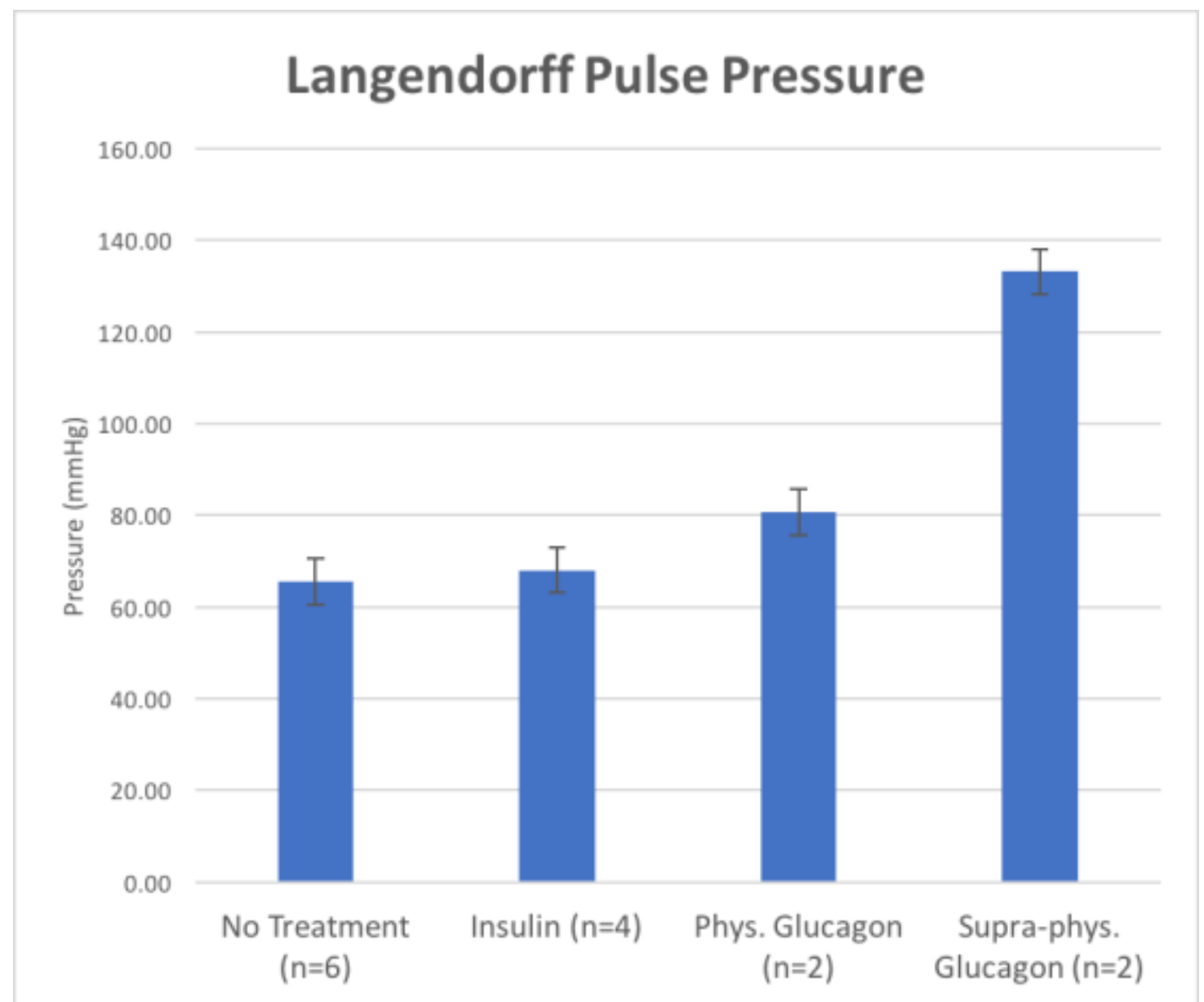

Figure 2: Average pulse pressure produced by each treatment. Pulse pressure was determine by taking the difference of the average maximal pressure minus the average minimal pressure. Bars represent average values and error bars represent the SEM. 


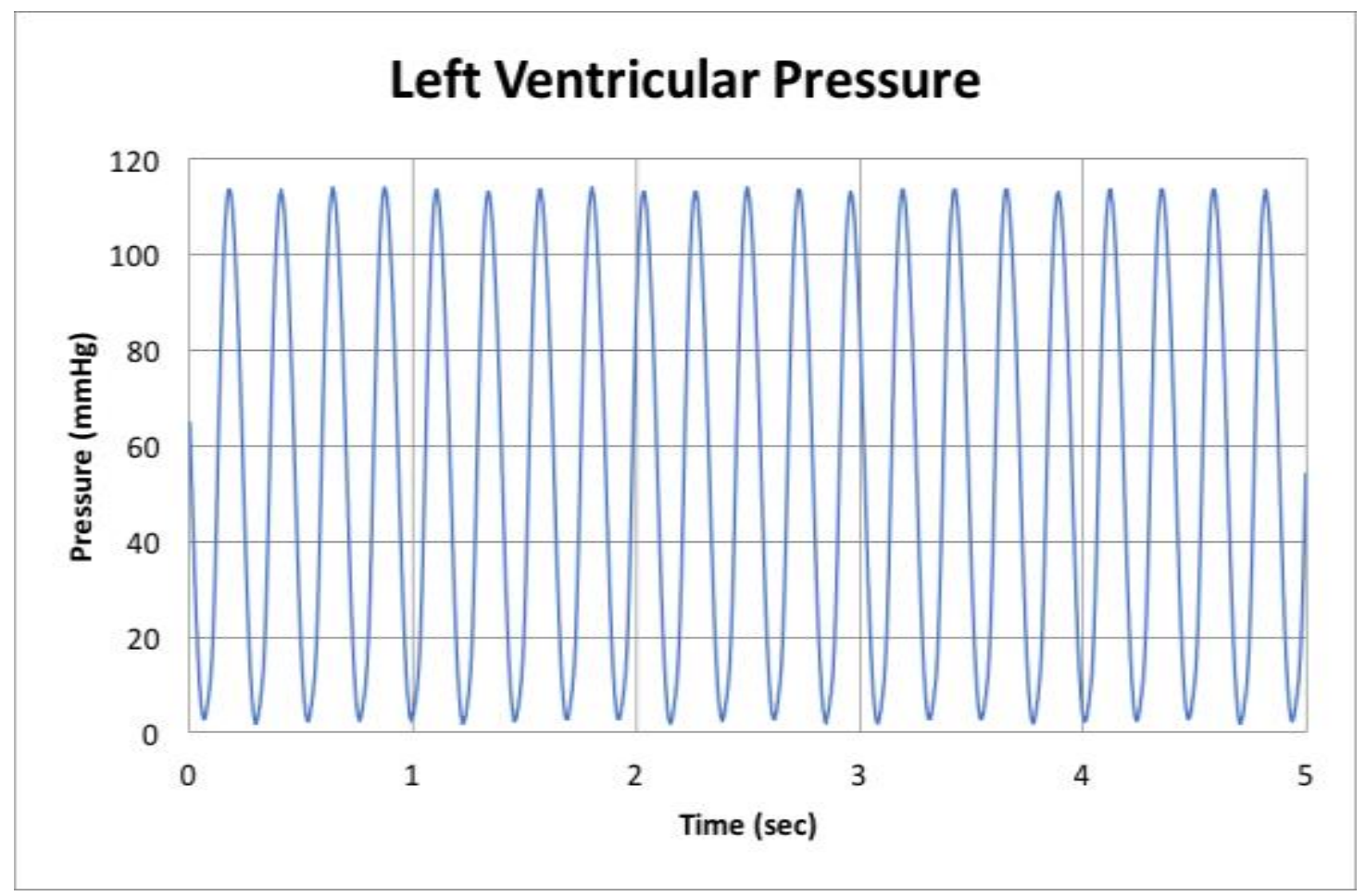

Figure 3: Representative pressure measurement for a heart perfused in the working mode. This graph was shows the pressure produced by the left ventricle after 10 minute of perfusion. The difference between the maximum and minimum pressure were averaged to determine pulse pressure. This heart was treated with no hormone. 


\section{Working Mode Pulse Pressure}

140

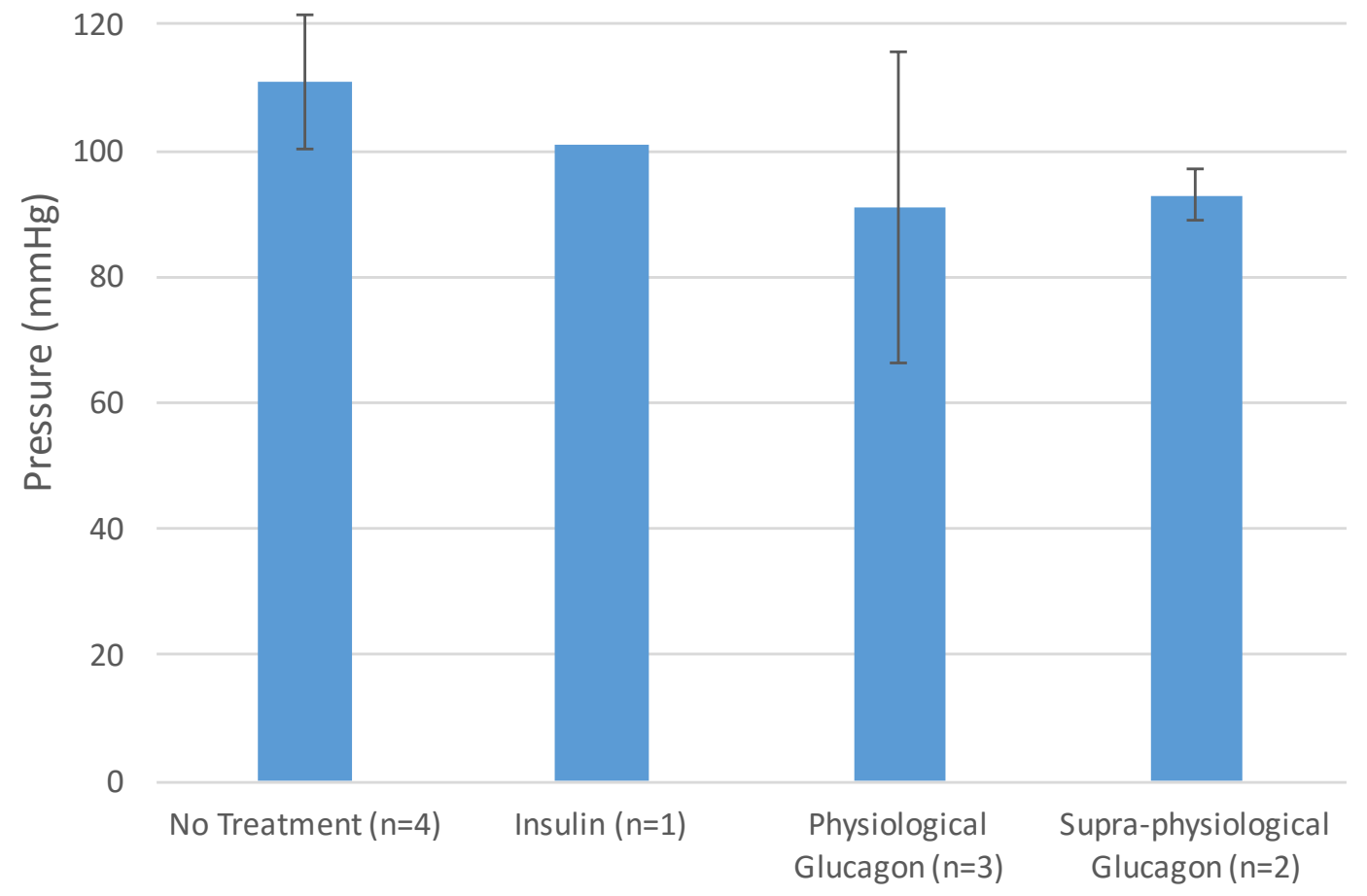

Figure 4: Average pulse pressure produced by each treatment. Pulse pressure was determined by taking the difference of the average maximal pressure minus the average minimal pressure. Bars represent average values and error bars represent SEM 


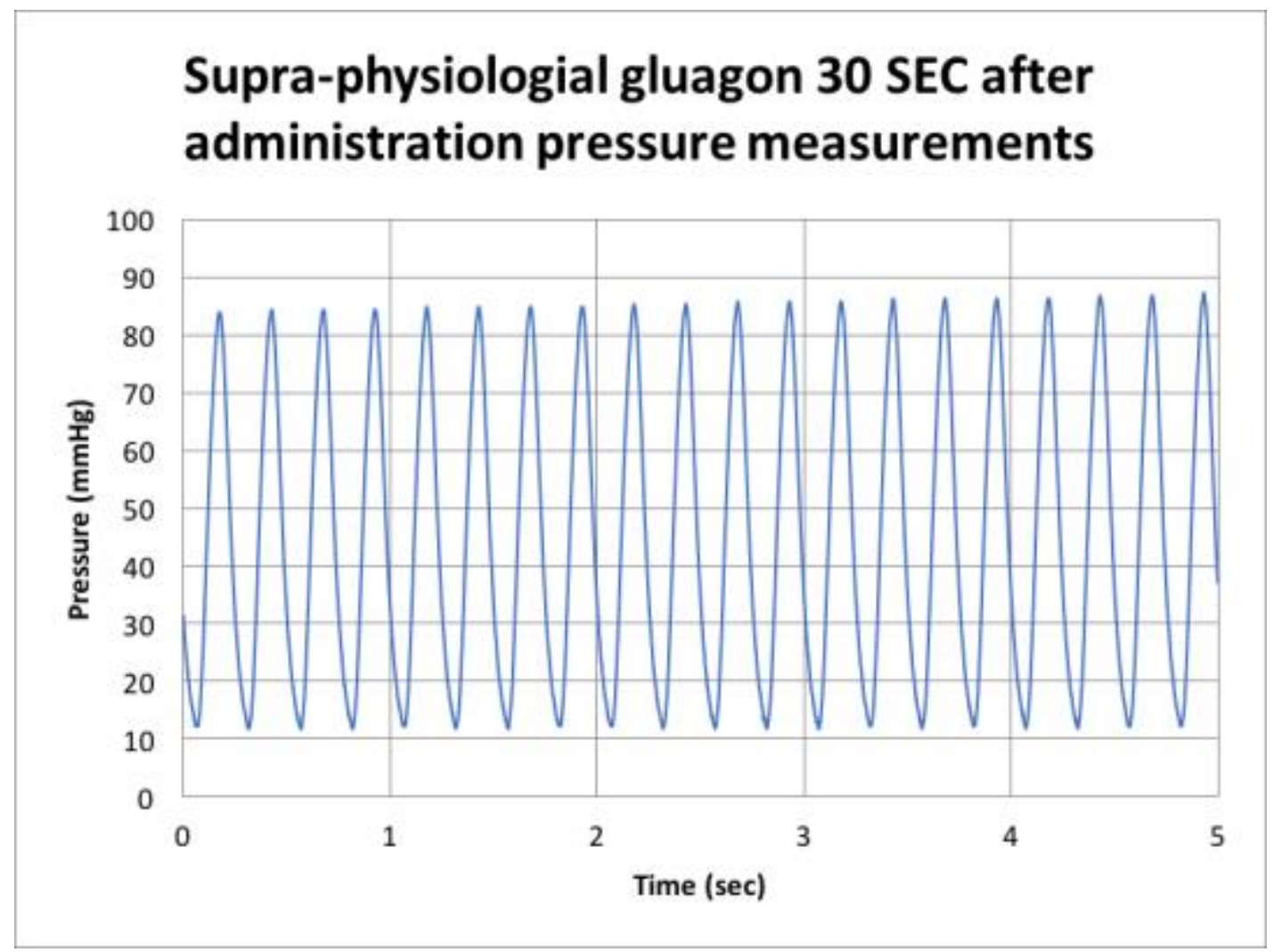

Figure 5 


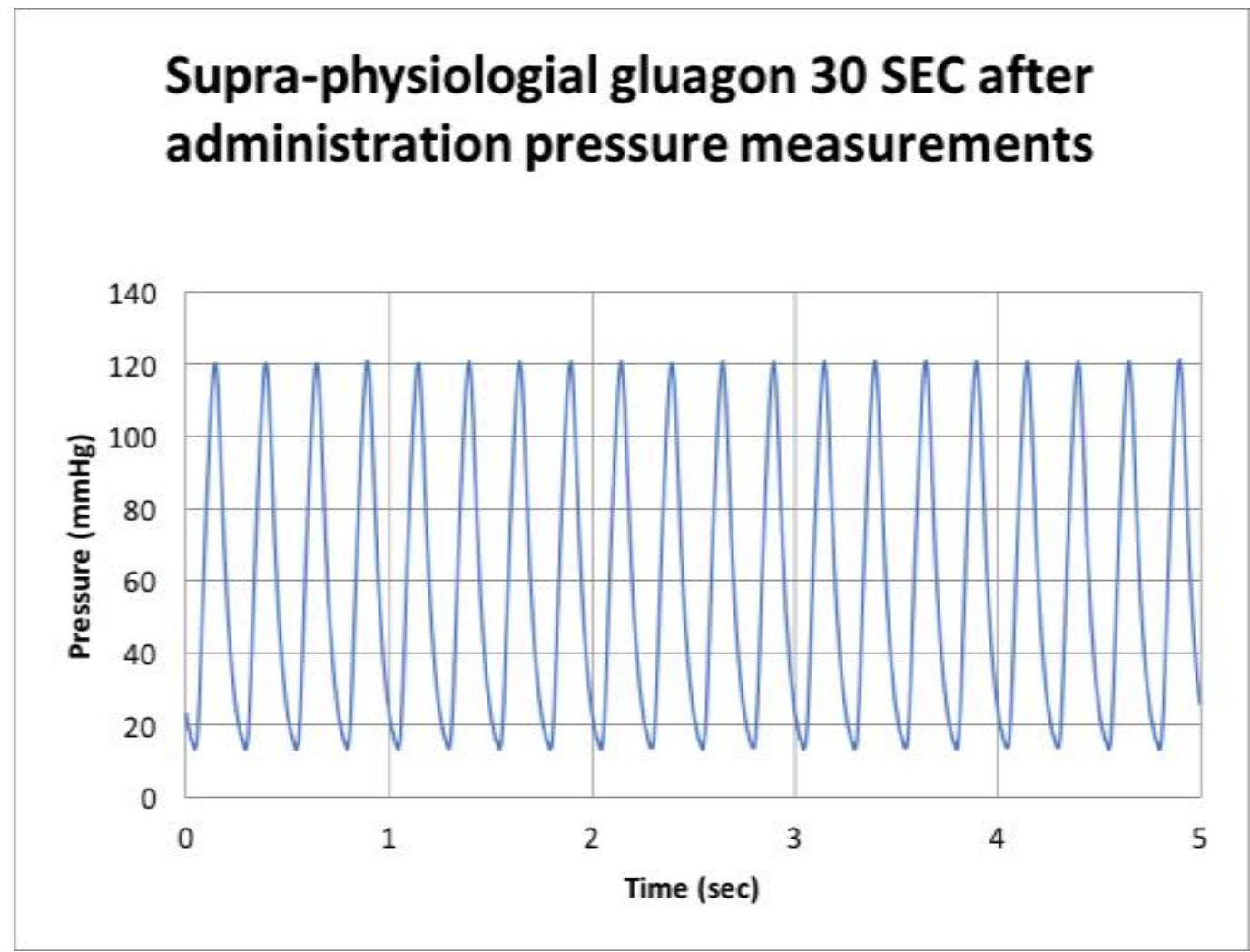

Figure 6 


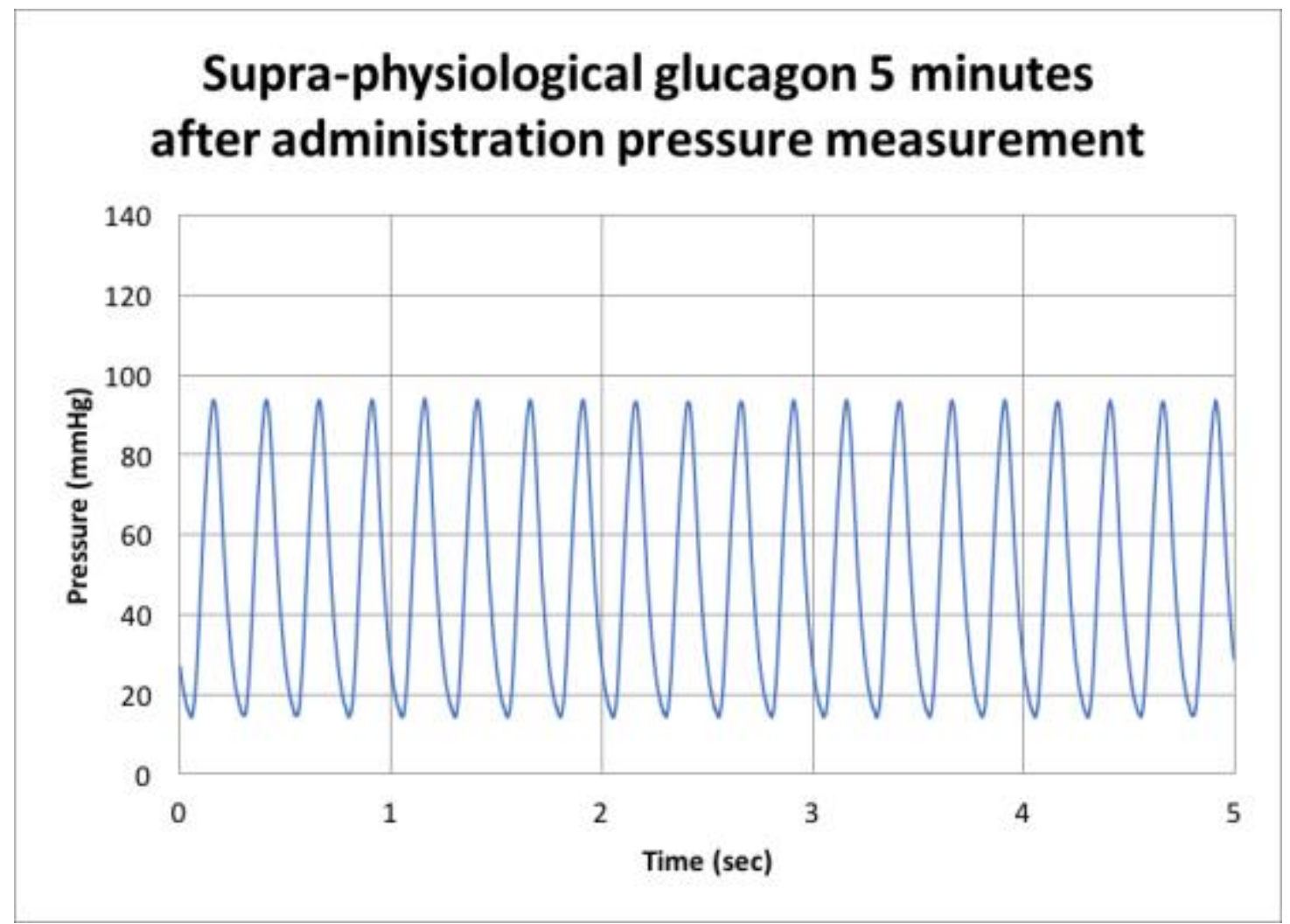

Figure 7

Figures 5, 6, and 7 are representative pressure tracings of one heart perfused via working mode. A supra-physiological glucagon concentration was administered at time zero. Each figure represents a different time point on the same heart. The pressure was determined by taking the difference of maximum value and the minimum value. 


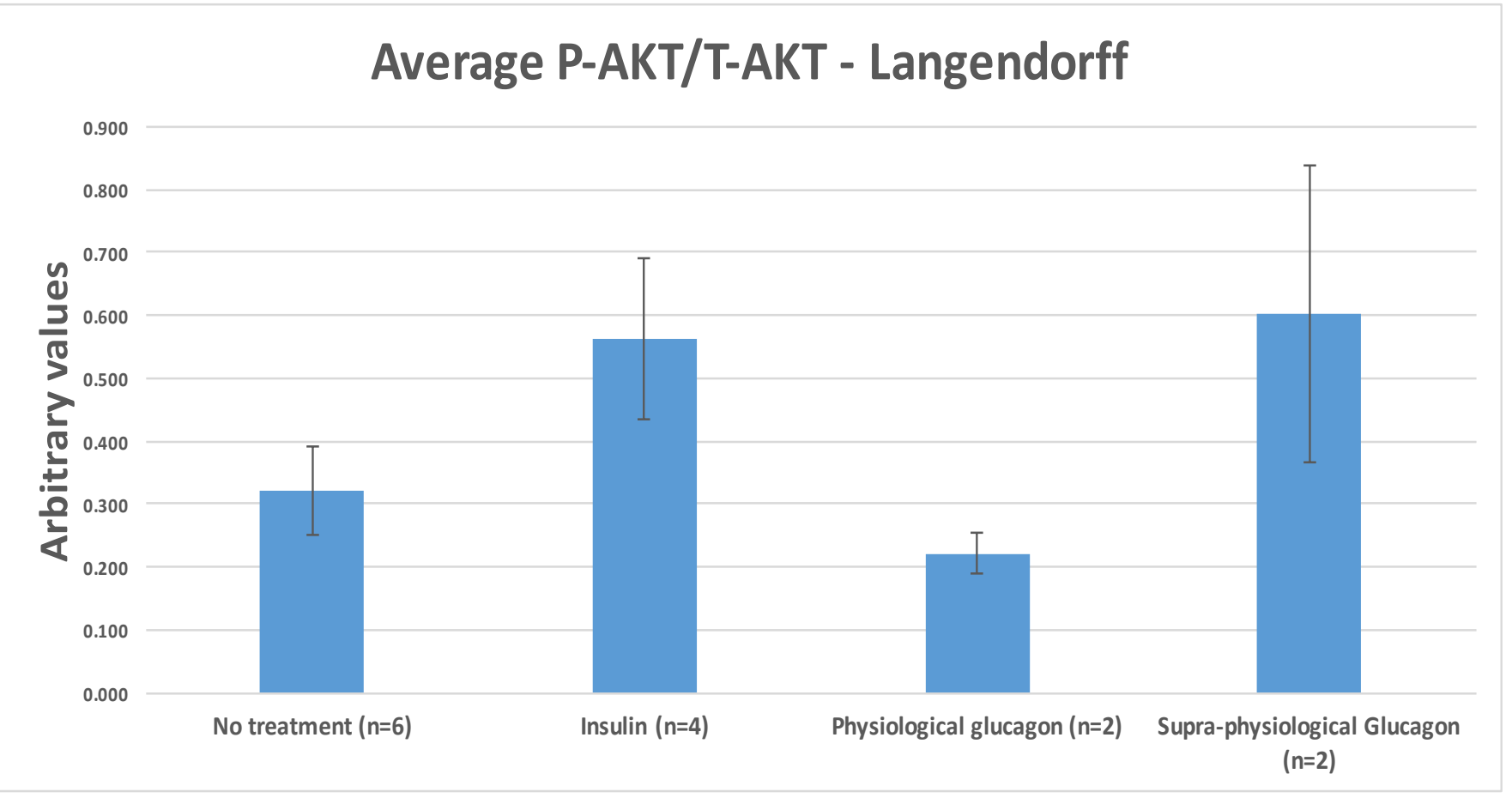

Figure 8: Average ratio of P-akt/T-akt for hearts perfused in the Langendorff Mode. Ratios represent the activation in PI3K/akt pathway. Error bars represent the SEM. 
Average P-AKT/T-AKT - Working Mode

1.4

1.2

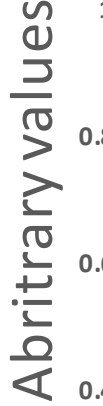

0.2

0

0.8

0.6

0.4

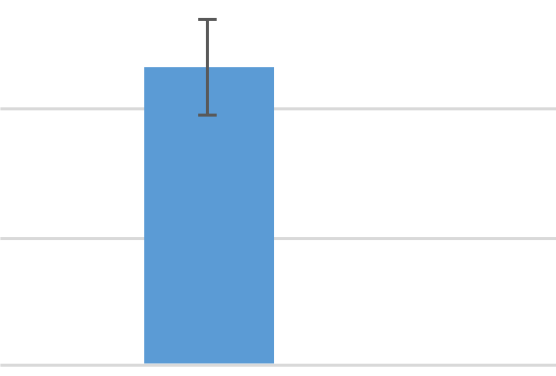

No treatment $(n=4)$

Insulin ( $\mathbf{n = 1 )}$

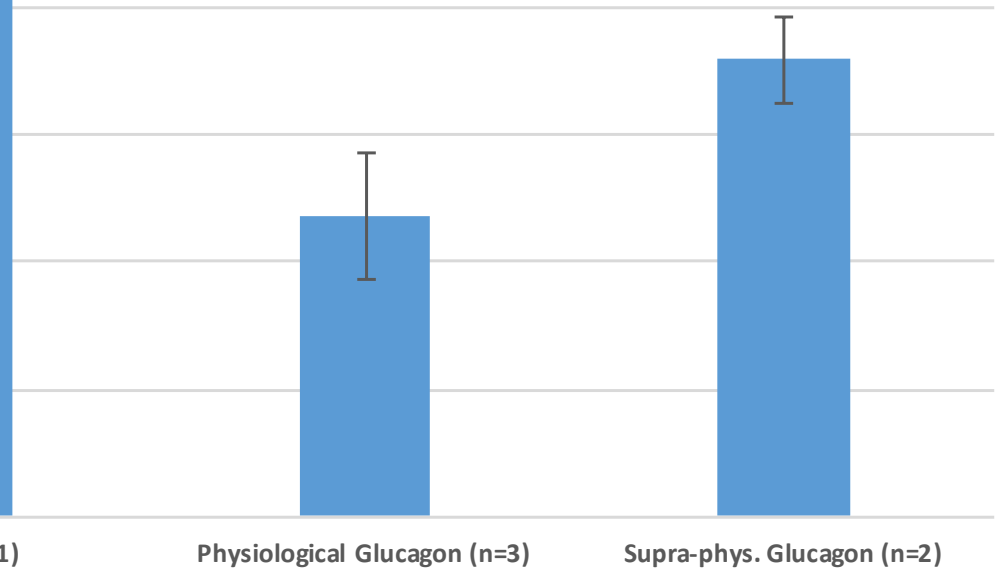

Figure 9: Average ratio of P-akt/T-akt for hearts perfused in the working Mode. Ratios represent the activation in PI3K/akt pathway. Error bars represent the standard deviation. Values represent means and error bars represent SEM 


\section{BIBLIOGRAPHY}

Ali, S., Ussher, J.R., Baggio, L.L., Kabir, M.G., Charron, M.J., Ilkayeva, O., Newgard, C.B., and Drucker, D.J. (2015). Cardiomyocyte glucagon receptor signaling modulates outcomes in mice with experimental myocardial infarction. Mol. Metab. 4, 132-143.

Aw, D.K.L., Sinha, R.A., Xie, S.Y., and Yen, P.M. (2014). Differential AMPK phosphorylation by glucagon and metformin regulates insulin signaling in human hepatic cells. Biochem. Biophys. Res. Commun. 447, 569-573.

Axelsen, L., Keung, W., Pedersen, H., Meier, E., Riber, D., Kjølbye, A., Petersen, J., Proctor, S., Holstein-Rathlou, N.-H., and Lopaschuk, G. (2012). Glucagon and a glucagon-GLP-1 dual-agonist increases cardiac performance with different metabolic effects in insulin-resistant hearts. Br. J. Pharmacol. 165, 2736-2748.

Bazan, C., Barba, D.T., Blomgren, P., and Paolini, P. (2010). Image Processing Techniques for Assessing Contractility in Isolated Adult Cardiac Myocytes. Int. J. Biomed. Imaging 2009, e352954.

Bonnevie-Nielsen, V., and Tager, H.S. (1983). Glucagon receptors on isolated hepatocytes and hepatocyte membrane vesicles. Discrete populations with ligand- and environment-dependent affinities. J. Biol. Chem. 258, 1131311320.

Broderick, T.L., Quinney, H.A., and Lopaschuk, G.D. (1992). Carnitine stimulation of glucose oxidation in the fatty acid perfused isolated working rat heart. J. Biol. Chem. 267, 3758-3763.

Chanut, F., Kimbrough, C., Hailey, R., Berridge, B., Hughes-Earle, A., Davies, R., Roland, K., Stokes, A., Casartelli, A., York, M., et al. (2013). Spontaneous cardiomyopathy in young Sprague-Dawley rats: evaluation of biological and environmental variability. Toxicol. Pathol. 41, 1126-1136.

Durham, B.C., and Miller, H.I. (1975). Myocardial Metabolism during Pentobarbital Anesthesia in Dogs. J. Am. Soc. Anesthesiol. 42, 464-470.

Fu, Q., Xu, B., Liu, Y., Parikh, D., Li, J., Li, Y., Zhang, Y., Riehle, C., Zhu, Y., Rawlings, T., et al. (2014). Insulin Inhibits Cardiac Contractility by Inducing a Gi-Biased $\beta 2$-Adrenergic Signaling in Hearts. Diabetes 63, 2676-2689.

Gandhi, M., Finegan, B.A., and Clanachan, A.S. (2008). Role of glucose metabolism in the recovery of postischemic LV mechanical function: effects of insulin and other metabolic modulators. Am. J. Physiol. - Heart Circ. Physiol. 294, H2576-H2586. 
Gonzalez-Muñoz, C., Nieto-Cerón, S., Cabezas-Herrera, J., and Hernández-Cascales, J. (2008). Glucagon increases contractility in ventricle but not in atrium of the rat heart. Eur. J. Pharmacol. 587, 243-247.

Griecsová, L., Farkašová, V., Gáblovský, I., Khandelwal, V.K.M., Bernátová, I., Tatarková, Z., Kaplan, P., and Ravingerová, T. (2015). Effect of maturation on the resistance of rat hearts against ischemia. Study of potential molecular mechanisms. Physiol. Res. 64 Suppl 5, S685-S696.

Harney, J.A., and Rodgers, R.L. (2008). Insulin-like stimulation of cardiac fuel metabolism by physiological levels of glucagon: involvement of PI3K but not cAMP. Am. J. Physiol. - Endocrinol. Metab. 295, E155-E161.

Heeneman, S., Cleutjens, J.P., Faber, B.C., Creemers, E.E., van Suylen, R.-J., Lutgens, E., Cleutjens, K.B., and Daemen, M.J. (2003). The dynamic extracellular matrix: intervention strategies during heart failure and atherosclerosis. J. Pathol. 200, 516-525.

Henderson, A.H., Most, A.S., Parmley, W.W., Gorlin, R., and Sonnenblick, E.H. (1970). Depression of Myocardial Contractility in Rats by Free Fatty Acids during Hypoxia. Circ. Res. 26, 439-449.

Ikezawa, Y., Yamatani, K., Ogawa, A., Ohnuma, H., Igarashi, M., Daimon, M., Manaka, H., and Sasaki, H. (1998). Effects of glucagon on glycogenolysis and gluconeogenesis are region-specific in periportal and perivenous hepatocytes. J. Lab. Clin. Med. 132, 547-555.

Jelinek, L.J., Lok, S., Rosenberg, G.B., Smith, R.A., Grant, F.J., Biggs, S., Bensch, P.A., Kuijper, J.L., Sheppard, P.O., Sprecher, C.A., et al. (1993). Expression cloning and signaling properties of the rat glucagon receptor. Science 259, 1614-1616.

Jiang, G., and Zhang, B.B. (2003). Glucagon and regulation of glucose metabolism. Am. J. Physiol. - Endocrinol. Metab. 284, E671-E678.

Juan-Fita, M.J., Vargas, M.L., Kaumann, A.J., and Cascales, J.H. (2004). Rolipram reduces the inotropic tachyphylaxis of glucagon in rat ventricular myocardium. Naunyn. Schmiedebergs Arch. Pharmacol. 370, 324-329.

Lee, J., and Pilch, P.F. (1994). The insulin receptor: structure, function, and signaling. Am. J. Physiol. 266, C319-C334.

Louch, W.E., Sheehan, K.A., and Wolska, B.M. (2011). Methods in Cardiomyocyte Isolation, Culture, and Gene Transfer. J. Mol. Cell. Cardiol. 51, 288-298.

MacLeod, K.M., Rodgers, R.L., and McNeill, J.H. (1981). Characterization of glucagon-induced changes in rate, contractility and cyclic AMP levels in 
isolated cardiac preparations of the rat and guinea pig. J. Pharmacol. Exp. Ther. 217, 798-804.

Mann, D.L. (2002). Inflammatory Mediators and the Failing Heart. Circ. Res. 91, 988-998.

Méry, P.F., Brechler, V., Pavoine, C., Pecker, F., and Fischmeister, R. (1990). Glucagon stimulates the cardiac $\mathrm{Ca} 2+$ current by activation of adenylyl cyclase and inhibition of phosphodiesterase. Nature 345, 158-161.

Pilkis, S.J., Exton, J.H., Johnson, R.A., and Park, C.R. (1974). Effects of glucagon on cyclic AMP and carbohydrate metabolism in livers from diabetic rats. Biochim. Biophys. Acta BBA - Gen. Subj. 343, 250-267.

Rababa'h, A., Singh, S., Suryavanshi, S.V., Altarabsheh, S.E., Deo, S.V., and McConnell, B.K. (2014). Compartmentalization Role of A-Kinase Anchoring Proteins (AKAPs) in Mediating Protein Kinase A (PKA) Signaling and Cardiomyocyte Hypertrophy. Int. J. Mol. Sci. 16, 218-229.

Rodgers, R.L. (2012). Glucagon and cyclic AMP: time to turn the page? Curr. Diabetes Rev. 8, 362-381.

Rodgers, R.L., MacLeod, K.M., and McNeill, J.H. (1981). Responses of rat and guinea pig hearts to glucagon. Lack of evidence for a dissociation between changes in myocardial cyclic 3'5'-adenosine monophosphate and contractility. Circ. Res. 49, 216-225.

Rodgers, R.L., Christe, M.E., Tremblay, G.C., Babson, J.R., and Daniels, T. (2001a). Insulin-like effects of a physiologic concentration of carnitine on cardiac metabolism. Mol. Cell. Biochem. 226, 97-105.

Rodgers, R.L., Christe, M.E., Tremblay, G.C., Babson, J.R., and Daniels, T. (2001b). Insulin-like effects of a physiologic concentration of carnitine on cardiac metabolism. Mol. Cell. Biochem. 226, 97-105.

Rook, M.B., van Ginneken, A.C., de Jonge, B., Aoumari, A. el, Gros, D., and Jongsma, H.J. (1992). Differences in gap junction channels between cardiac myocytes, fibroblasts, and heterologous pairs. Am. J. Physiol. 263, C959C977.

Salazar, N.C., Chen, J., and Rockman, H.A. (2007). Cardiac GPCRs: GPCR signaling in healthy and failing hearts. Biochim. Biophys. Acta BBA - Biomembr. 1768, $1006-1018$.

Saltiel, A.R., and Kahn, C.R. (2001). Insulin signalling and the regulation of glucose and lipid metabolism. Nature 414, 799-806. 
Sangaralingham, S.J., Wang, B.H., Huang, L., Kumfu, S., Ichiki, T., Krum, H., and Burnett Jr., J.C. (2016). Cardiorenal fibrosis and dysfunction in aging: Imbalance in mediators and regulators of collagen. Peptides 76, 108-114.

Schechter, M.A., Southerland, K.W., Feger, B.J., Linder, D., Ali, A.A., Njoroge, L., Milano, C.A., and Bowles, D.E. (2014). An Isolated Working Heart System for Large Animal Models. J. Vis. Exp. JoVE.

Shimizu, T., Yamato, M., Isoi, Y., Akutsu, T., Setomaru, T., Abe, K., Kikuchi, A., Umezu, M., and Okano, T. (2002). Fabrication of Pulsatile Cardiac Tissue Grafts Using a Novel 3-Dimensional Cell Sheet Manipulation Technique and Temperature-Responsive Cell Culture Surfaces. Circ. Res. 90, e40-e48.

Skrzypiec-Spring, M., Grotthus, B., Szeląg, A., and Schulz, R. (2007). Isolated heart perfusion according to Langendorff-Still viable in the new millennium. J. Pharmacol. Toxicol. Methods 55, 113-126.

Soliman, D., Wang, L., Hamming, K.S.C., Yang, W., Fatehi, M., Carter, C.C., Clanachan, A.S., and Light, P.E. (2012). Late Sodium Current Inhibition Alone with Ranolazine Is Sufficient to Reduce Ischemia- and Cardiac GlycosideInduced Calcium Overload and Contractile Dysfunction Mediated by ReverseMode Sodium/Calcium Exchange. J. Pharmacol. Exp. Ther. 343, 325-332.

Taborsky, G.J. (2010). The Physiology of Glucagon. J. Diabetes Sci. Technol. 4, $1338-1344$.

Tang, C.-M., and Insel, P.A. (2004). GPCR Expression in the Heart: "New" Receptors in Myocytes and Fibroblasts. Trends Cardiovasc. Med. 14, 94-99.

Towle, H.C. (2001). Glucose and cAMP: adversaries in the regulation of hepatic gene expression. Proc. Natl. Acad. Sci. U. S. A. 98, 13476-13478.

Tuncok, Y., Apaydin, S., Gidener, S., Guven, H., Oto, O., Ates, M., and Gure, A. (1997). The effects of amrinone and glucagon on verapamil-induced myocardial depression in a rat isolated heart model. Gen. Pharmacol. Vasc. Syst. 28, 773-776.

Unger, R.H. (1971). Glucagon and the Insulin:Glucagon Ratio in Diabetes and Other Catabolic Illnesses. Diabetes 20, 834-838.

Xiao, R.P., Tomhave, E.D., Wang, D.J., Ji, X., Boluyt, M.O., Cheng, H., Lakatta, E.G., and Koch, W.J. (1998). Age-associated reductions in cardiac beta1- and beta2-adrenergic responses without changes in inhibitory $\mathrm{G}$ proteins or receptor kinases. J. Clin. Invest. 101, 1273-1282.

Zhao, A.Z., Shinohara, M.M., Huang, D., Shimizu, M., Eldar-Finkelman, H., Krebs, E.G., Beavo, J.A., and Bornfeldt, K.E. (2000). Leptin Induces Insulin-like 
Signaling That Antagonizes cAMP Elevation by Glucagon in Hepatocytes. J. Biol. Chem. 275, 11348-11354.

(2017). Charles River Laboratory. 